\title{
THE ROLE OF FEDERAL AND STATE DEPENDENT COVERAGE ELIGIBILITY POLICIES ON THE HEALTH INSURANCE STATUS OF YOUNG ADULTS
}

\author{
Joel C. Cantor \\ Alan C. Monheit \\ Derek DeLia \\ Kristen Lloyd \\ Working Paper 18254 \\ http://www.nber.org/papers/w18254 \\ NATIONAL BUREAU OF ECONOMIC RESEARCH \\ 1050 Massachusetts Avenue \\ Cambridge, MA 02138 \\ July 2012
}

An abbreviated version of this paper is in press at + HDOK6HUIFHI5HMDFK Support provided by the State Health Access Reform Evaluation (SHARE) Initiative of the Robert Wood Johnson Foundation. The views expressed herein are those of the authors and do not necessarily reflect the views of the National Bureau of Economic Research.

NBER working papers are circulated for discussion and comment purposes. They have not been peerreviewed or been subject to the review by the NBER Board of Directors that accompanies official NBER publications.

(C) 2012 + HDON6HUIFHN5 HHDFKIFLFXOUMGZZ LWSHP LMRQ All rights reserved.IShort sections of text, not to exceed two paragraphs, may be quoted without explicit permission provided that full credit, including $(\mathcal{C}$ notice, is given to the source. 
The Role of Federal and State Dependent Coverage Eligibility Policies on the Health Insurance Status of Young Adults

Joel C. Cantor, Alan C. Monheit, Derek DeLia, and Kristen Lloyd

NBER Working Paper No. 18254

July 2012

JEL No. I13,I18

\begin{abstract}
$\underline{\text { ABSTRACT }}$
This paper evaluates one of the first implemented provisions of the Patient Protection and Affordable Care Act (ACA) which permits young adults up to age 26 to enroll as dependents on a parent's private health plan. The paper also considers how the interaction between prior state laws expanding dependent coverage to young adults and the ACA affected young adult coverage. Using data from the Current Population Survey for calendar years 2004-2010, we apply a difference-in-differences framework to estimate how these provisions affected coverage of eligible young adults compared to slightly older adults. Our findings indicate that controlling for state laws, early implementation of the ACA increased young adult dependent coverage by 5.3 percentage points and resulted in a 3.5 percentage point decline in their uninsured rate. The interaction between state laws and the ACA suggests that the increase in dependent coverage and decline in the uninsured rate may have been greater among young adults who were targeted by both the ACA and state laws.
\end{abstract}

Joel C. Cantor

112 Paterson Street, 5th Floor

New Brunswick, NJ 08840

jcantor@ifh.rutgers.edu

Alan C. Monheit

School of Public Health

University of Medicine and Dentistry of

New Jersey (UMDNJ)

683 Hoes Lane West

Piscataway, NJ 08854-5635

and NBER

monheiac@umdnj.edu
Derek DeLia

112 Paterson Street, 5th Floor

New Brunswick, NJ 08840

ddelia@ifh.rutgers.edu

Kristen Lloyd

112 Paterson Street, 5th Floor

New Brunswick, NJ 08840

klloyd@ifh.rutgers.edu 


\section{Introduction}

One of the first implemented provisions of the Patient Protection and Affordable Care Act (ACA) permits young adults up to age 26 to obtain health insurance as dependents on a parent's private health plan. This provision recognized that young adults are the age group most likely to lack health insurance. In 2009, the year before the ACA dependent coverage expansion, 31.4\% of adults in the targeted age range, 19 to 25 years old, lacked coverage, nearly double the national rate (DeNavas-Walt, Proctor, and Smith 2011). This high likelihood of being without coverage has compromised young adults' access to health services, their financial protection against incurring substantial medical debt, and the ability to address their frequently observed obesity and alcohol and tobacco use that lead to health and economic problems in later adulthood (Nicholson et al. 2009; Callahan and Cooper 2005; Merluzzi and Nairn 1999).

The ACA dependent coverage provision builds upon laws enacted by the nearly twothirds of states that sought to expand young adult coverage (Cantor et al. 2012). Two evaluations of the state-level expansions found increases in young adult dependent coverage that were offset by reductions in other sources of coverage (Monheit et al. 2011; Levine, McKnight, and Heep 2011). One of these studies tested the impact of these state policies on the number of uninsured young adults and found no net impact (Monheit et al. 2011). ACA dependent coverage rules promise to improve upon prior state expansions, since the federal law includes more liberal eligibility requirements and it extends to young adults whose parents are enrolled in large selfinsured group plans that are exempt from state laws.

A variety of early descriptive analyses suggest a substantial impact of the ACA's dependent coverage provision (Fronstin 2012; Mendes 2011; Martinez and Cohen 2011). One analysis estimated that the number of young adults (ages 19 to 25) with health insurance 
increased by 2.5 million between the September 2010 and June 2011 without a corresponding coverage increase for those aged 26 to 35 (Sommers and Schwartz 2011). These trends are consistent with a 2011 study that estimated large numbers of employers enrolling young adult dependents under the ACA rules (Claxton et al. 2011).

Most prior analyses of the ACA young adult provision have not specifically examined its direct impact on dependent coverage and none have rigorously identified the early impact of the federal law apart from the contribution of prior state laws and prevailing economic conditions. Although Sommers and Kronick (2012) found a statistically significant increase in private coverage of young adults eligible to enroll as dependents under the ACA (ages 19 to 25) relative to a slightly older age group (ages 26 to 34 ) between $2005-2009$ and 2010, their study did not control for possible differences between ACA-targeted young adults and their control group in demographic characteristics, eligibility for state dependent coverage expansions, or for economic trends. As regards the latter, the weak economy over this period made it more difficult for young adults to find jobs that offer coverage, and encouraged them to retain student status or live with their parents, possibly contributing to increased enrollment through a parent's plan.

Most recently, Antwi, Moriya, and Simon (2012) have applied an econometric framework to examine the impact of the ACA dependent coverage provision using data from the Survey of Income and Program Participation from August 2008 to November 2011. Consistent with our findings from the Current Population Survey, they find that early implementation of this ACA provision resulted in an increase in young adult dependent coverage and a decline in their uninsured rate. While the authors consider the impact of state laws on dependent coverage, they do so indirectly, applying models with state fixed effects, state linear time trends, and fitting separate model for states with and without the reform provisions. Their results do not indicate 
that state laws differentially affected the impact of the ACA on young adult coverage. By contrast, our econometric analysis explicitly includes variables for the presence of state laws and for young adults targeted by the state laws. Our findings suggest that the increase in dependent coverage and the decline in uninsured rates may have been greater among young adults who were targeted by both the state laws and the ACA.

The goal of our study is to provide a rigorous analysis of this ACA coverage provision, which controls for the inter-relationship between the ACA young adult provisions and prior state-level reforms, young adult characteristics, and economic trends.

\section{The ACA Young Adult Dependent Coverage Provision and Prior State Laws}

Beginning with the first plan renewal as of September 23, 2010, the ACA requires health insurers and employer group plans, including self-insured plans, to provide coverage to dependents under age 26 (P.L. 111-152 §2301). This requirement applies to all adult children under age 26 regardless of marital status, residency, financial dependency, or other characteristics. Plans held prior to the ACA, known as "grandfathered plans," are not required to enroll young adult dependents who are offered employer-sponsored coverage. However, beginning in 2014 even grandfathered plans will be required to cover young adult dependents regardless of whether they are offered a plan. Plans covering young adult dependents may not treat them differently than other dependents in determining benefits or premiums. The ACA also extended the same favorable tax treatment afforded other employer-sponsored insurance premiums to the coverage of young adult dependents through the end of the tax year of their $26^{\text {th }}$ birthday. 
State laws effective prior to implementation of the ACA's dependent coverage provision are displayed in Table 1 and reveal variation in both timing and eligibility requirements. As noted, these prior state laws were more limited than the ACA young adult expansion, applying only to state regulated plans but not large employer self-funded plans (except for public employee plans in some states). Moreover, of the states implementing dependent coverage expansions by early 2011, all but a few were limited to unmarried young adults (Cantor, et al. 2012). Most of the reform states also imposed state residency requirements, at least for nonstudents; and some (nine states) required or explicitly permitted insurers to charge added premiums for enrolled young adults beyond standard family premiums. The federal law does not include any of these limitations, and effectively preempts these state restrictions for young adults under age 26. On the other hand, nine states laws authorize young adult dependent coverage above the federal limit of age 26 , including five states that allow enrollment up to age 30 or 31 and two other states have no upper age limit for full-time students. These state provisions for older young adults are unaffected by the ACA.

\section{Data and Methods}

\section{Data Sources and Study Population}

Data are drawn from the 2005 to 2011 Annual Social and Economic Supplement to the Current Population Survey (CPS), which measures coverage status for calendar years 2004 to 2010 (DeNavas-Walt, Proctor, and Smith 2011). To adjust for potentially confounding trends in state economic conditions and health insurance markets, we link CPS records to annual statelevel data on unemployment rates (BLS n.d.), employer health insurance offer rates (MEPS 2010b), and the extent of employer self-insurance (MEPS 2010a). We exclude Hawaii and 
Massachusetts from the analysis because coverage in those states is likely to be influenced by their respective employer and individual coverage mandates. ${ }^{1}$

Two age groups are included in our analysis. First, we define the young adult population targeted for dependent coverage by the ACA as persons ages 19 to 23 who are not full-time students and all young adults ages 24 or 25 regardless of student status. Prior to the ACA, fulltime students up to age 23 were generally eligible to remain on a parent's plan. Second, we use persons ages 27 to 30 who are not eligible for dependent coverage under the ACA as a comparison group. Individuals reported as age 26 are excluded from the analysis because the CPS does not provide sufficient information to determine their age-eligibility during the portion of 2010 when the ACA dependent coverage rules were in effect. Our analysis sample includes 85,158 ACA-targeted young adults and 71,203 non-target comparison group observations.

\section{Analytic Approach and Econometric Model}

After describing changes in sources of coverage between ACA-targeted and comparison groups from 2004 to 2010 and evaluating differences in characteristics of these groups over the

study period, we treat implementation of the ACA's dependent coverage expansion as a "natural experiment" and consider how young adult coverage changed after implementation. To do so, we use a "difference-in-differences" (DD) framework to examine changes in health insurance status of the group targeted by the ACA from the pre- to post-implementation period relative to the change in the non-targeted group. This contrast is made through a series of multivariate linear probability models that adjust for non-policy related factors that may affect coverage as well as eligibility for state dependent coverage expansions.

Trends in four health insurance outcomes are examined over the study period: (1) private dependent coverage other than as a dependent of a spouse living in the same household; (2) 
private coverage as a policyholder or dependent of a spouse living in the same household; (3) public coverage, including Medicaid or Medicare; and (4) no coverage during the year (i.e., uninsured). Study subjects with more than one type of coverage during the year are recorded in each applicable category, thus the categories other than "no coverage" are not mutually exclusive. For example, $18.1 \%$ and $35.2 \%$, respectively, of the ACA-targeted and comparison groups with non-spousal dependent coverage had some other form of coverage reported in 2010. These percentages did not change significantly with ACA implementation between 2009-2010.

Regression models for each coverage outcome are specified as follows, with $\mathrm{COV}_{\text {ist }}$ representing the respective dichotomous coverage outcome variable for individual $i$, living in state $\mathrm{s}$, and in year $\mathrm{t}$ :

$$
\begin{aligned}
& \mathrm{COV}_{\text {ist }}=\mathrm{a}_{1}+\mathrm{a}_{2} \text { FED_TARGET }_{\mathrm{i}}+\mathrm{a}_{3} \mathrm{ST}_{-} \mathrm{TARGET}_{\mathrm{is}}+\mathrm{a}_{4} \mathrm{ST}_{-} \text {POLICY }_{\mathrm{st}}+\mathrm{a}_{5} \text { TREND }_{\mathrm{t}}+\sum_{\mathrm{t}} \mathrm{b}_{\mathrm{t}} \text { YEAR }_{\mathrm{t}}+
\end{aligned}
$$

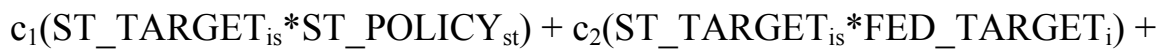

$$
\begin{aligned}
& \mathrm{c}_{3}\left(\mathrm{ST}_{-} \mathrm{POLICY}_{\mathrm{st}} * \mathrm{FED}_{-} \text {TARGET }\right)+\mathrm{c}_{4}\left(\mathrm{ST}_{-} \text {POLICY }{ }_{\mathrm{st}} * \mathrm{YEAR}_{2010}\right)+ \\
& \mathrm{c}_{5}\left(\mathrm{FED}_{-} \mathrm{TARGET}_{\mathrm{i}} * \mathrm{YEAR}_{2010}\right)+\mathrm{c}_{6}\left(\mathrm{ST}_{-} \mathrm{TARGET}_{\mathrm{is}} * \mathrm{ST}_{-} \mathrm{POLICY}_{\mathrm{st}} * \mathrm{FED}_{-} \mathrm{TARGET}_{\mathrm{i}}\right)+ \\
& \mathrm{c}_{7}\left(\mathrm{ST}_{-} \mathrm{TARGET}_{\mathrm{is}}{ }^{*} \mathrm{ST}_{-} \mathrm{POLICY}_{\mathrm{st}} * \mathrm{YEAR}_{2010}\right)+\mathrm{c}_{8}\left(\mathrm{ST}_{-} \mathrm{POLICY}_{\mathrm{st}} * \mathrm{FED}_{-} \mathrm{TARGET}_{\mathrm{i}}{ }^{*} \mathrm{YEAR}_{2010}\right)+ \\
& \mathrm{c}_{9}\left(\mathrm{ST}_{-} \mathrm{TARGET}_{\mathrm{is}}{ }^{*} \mathrm{ST} \_ \text {POLICY }_{\mathrm{st}} * \mathrm{FED}_{-} \mathrm{TARGET}_{\mathrm{i}} * \mathrm{YEAR}_{2010}\right)+\sum_{\mathrm{k}} \mathrm{d}_{\mathrm{k}} \mathrm{X}_{\mathrm{kit}}+\sum_{\mathrm{r}} \mathrm{f}_{\mathrm{r}} \mathrm{Z}_{\mathrm{rst}}+ \\
& \sum_{\mathrm{s}} \mathrm{g}_{\mathrm{s}} \mathrm{STATE}_{\mathrm{s}}+\sum_{\mathrm{s}} \mathrm{h}_{\mathrm{s}}\left(\mathrm{STATE}_{\mathrm{s}} * \mathrm{TREND}_{\mathrm{t}}\right)+\mathrm{e}_{\mathrm{ist}}
\end{aligned}
$$

Two dichotomous variables, FED_TARGET ${ }_{\mathrm{i}}$ and $\mathrm{ST}_{-} \mathrm{TARGET}_{\mathrm{i}}$, indicate whether young adults would have met the eligibility requirements for expanded dependent coverage, respectively under the ACA or a state law, regardless of whether these laws were actually in effect at the time of the CPS interview. Thus, these target variables are time-invariant in our models and control for underlying propensity of these individuals to have or not have specific types of coverage throughout the study period. Eligibility for the ACA is based solely on age. Reflecting the provisions of individual state laws, $\mathrm{ST}_{-} \mathrm{TARGET}_{\text {is }}$ is assigned based on the young adults' state of residence, age, marital status, whether they have their own dependents, whether they live with 
a parent, and their student status. The CPS lacks information about the insurance status of the parents of young adults not living with them, for example whether parents are covered by a state regulated plan. Thus, $\mathrm{ST}_{-}$TARGET is $_{\text {d }}$ does not take parental insurance status into account. (As discussed below, our models include state-level variables to adjust for likelihood that parents are enrolled in state-regulated plans.)

ST_POLICY $\mathrm{st}_{\text {st }}$ is a state policy implementation flag which is set to 1 for all individuals living in a state with a dependent coverage expansion during the years in which the expansion was in effect. This variable equals 0 for all individuals living in an expansion state during the pre-expansion years and for individuals in non-expansion states during all study years. The models also include a linear trend variable $\left(\mathrm{TREND}_{\mathrm{t}}\right)$ as well as annual indicator variables $\left(\right.$ YEAR $\left._{t}\right)$. Implementation of the federal reform began September 23, 2010, but the CPS does not provide information on the timing of health insurance coverage during the calendar year. Thus we use the 2010 year indicator variable to flag federal policy implementation, which provides a conservative estimate of policy impact, since it includes a long period of time when the federal policy was not in effect. The $\mathrm{YEAR}_{2010}$ and ST_POLICY st indicator variables are used only to mark the time at which state and federal policies went into effect, and therefore, do not vary by any individual characteristics including whether the individual meets the criteria for federal or state coverage expansion.

Next, the models include a series of interaction terms among the target population and policy implementation indicator variables. We use alternative specifications of these terms to identify the policy impact of ACA young adult dependent rules. All of the specifications include the interaction of FED_TARGET ${ }_{i}$ and $\mathrm{YEAR}_{2010}$. The coefficient on this interaction term is the DD estimate of the impact of the ACA dependent coverage expansion. The first specification 
(referred to as Model 1) also includes the interaction of ST_TARGET is and ST_POLICY st, effectively controlling for individuals' eligibility for state dependent coverage expansions prior to the ACA.

The second model specification (Model 2) includes all possible two-way, three-way and the four-way interactions among these state and federal target and implementation variables (i.e., FED_TARGET ${ }_{i}, Y_{\text {YEAR }}$ 2010, ST_TARGET $_{\text {is }}$, and ST_POLICY st $_{\text {st }}$, with redundant terms omitted to avoid perfect co-linearity. ${ }^{2}$ In these models, two of the $c_{j}$ coefficients are used to generate DD estimators identifying ACA policy impact. First, the coefficient on the interaction of the variables indicating federal eligibility and implementation (i.e., FED_TARGET ${ }_{\mathrm{i}}^{*} \mathrm{YEAR}_{2010}$ ) is the DD estimator measuring the policy impact on young adults eligible for dependent coverage under federal rules but not eligible under any state law. Next, the coefficient on the four-way interaction between federal and state eligibility and policy indicators (i.e., FED_TARGET $_{\mathrm{i}} * \mathrm{YEAR}_{2010} * \mathrm{ST}_{-} \mathrm{TARGET}_{\mathrm{is}}{ }^{*} \mathrm{ST}$-POLICY st $)$ measures how the ACA's policy impact differs for young adults who were eligible both under prior state expansions and the federal expansion relative to those eligible under the federal expansion only. The sum of these two coefficients represents the incremental effect of the ACA's dependent coverage expansion on those who are jointly targeted by federal and prior state policies simultaneously.

As a robustness check, we estimate a third set of models (Model 3) that is limited to residents of 18 states and the District of Columbia that did not enact dependent coverage reforms prior to the ACA. These models test the impact of the ACA without the potential complicating influence of state reforms. Although similar to the Model 1 described above, this specification avoids the need for state target population and policy implementation variables and associated interaction terms. In addition, because the availability of dependent coverage might affect young 
adults' decisions about whether to enroll as full-time students, we conducted tests of the sensitivity of our Model 1 results to the inclusion of student variables and the exclusion of fulltime students ages 19-23 from our models (Models 4 and 5, respectively). Finally, we confirm our results by estimating a "placebo" model without data for coverage year 2010 that falsely assumes that the ACA was implemented in 2009 (Model 6).

All regression models control for non-policy factors that could affect coverage trends. Specifically, the models include individual-level variables $\mathrm{X}_{\mathrm{kit}}$ (indexed by variable $\mathrm{k}$ for person $\mathrm{i}$ in year $\mathrm{t}$ ) in order to adjust for age, sex, race and ethnicity, student status, marital status, living with a parent, household income as a percentage of the federal poverty line, and perceived health status. For each state and year, the models also include state-level variables $Z_{\text {rst }}$ (indexed by variable $r$ for state $s$ in year $t$ ) that include the unemployment rate (to adjust for state trends in economic conditions), the percentage of private sector employees working in establishments that offer health insurance coverage (to adjust for the likelihood that parents of young adults have employer group coverage), and the proportion of all enrollees in private group coverage that are in employer self-insured plans (to adjust for the extent to which self-insured plans are subject to the ACA but not state laws).

The models also include state and year fixed effects (represented by summations of respective state and year variables with their associated coefficients in the regression equation above) as well as overall and state-specific linear time trends to adjust for unobserved factors that vary by time and within states over time. Finally, $\mathrm{e}_{\mathrm{ist}}$ represents a stochastic error term.

\section{Estimation}

All analyses employ population weights provided by the Census Bureau and adjust standard errors for the CPS complex sample design following Davern et al. (2007). Linear 
probability models are fit to produce coefficients that are direct estimates of the relevant policy impacts and are easily interpreted as percentage point changes in coverage outcomes. This approach has been applied in earlier evaluations of insurance market reforms (Monheit et al. 2011; Levine, McKnight, and Heep 2011; Monheit and Steinberg Schone 2004; Buchmueller and DiNardo 2002). It also avoids complications associated with estimation and interpretation of multiple interaction terms and their standard errors in logit or probit models (Ai and Norton 2003).

All models account for the complex survey design of the CPS using "svy" procedures in STATA 12MP. In Model 2, the overall incremental effect of the ACA's dependent coverage expansion on individuals jointly eligible for state and federal expansions is calculated as the sum of two regression coefficients. The standard error for this estimated sum is based on a Wald statistic for complex survey regression (Korn and Graubard, 1990). This Wald statistic is calculated using the "lincom" procedure in Stata.

Although coefficient estimates in the linear probability model are unbiased and consistent, this model is often subject to the problem of heteroskedasticity, which leads to downward biased estimates of standard errors and can overstate the statistical significance of estimated coefficients (Pindyck and Rubinfeld, 1998). Although tests of heteroskedasticity are not available in the context of regression analysis with complex survey data, we tested the robustness of our findings by using ordinary regression models with "robust" standard errors that are insensitive to heteroskedasticity (Huber 1967; White 1980). (However, these ordinary regression models do include weights to account for differential probability of selection into the CPS.) We find that these heteroskedasticity-robust models produce results that are nearly identical to those reported in the main text and shown in detail below. 


\section{$\underline{\text { Results }}$}

The unadjusted percentage of young adults in the ACA target population with nonspousal dependent coverage rose by six percentage points between 2009 and 2010 (Table 2). This nearly one-third increase is statistically significant $(\mathrm{p}<0.01)$ and represents a growth of 1.2 million young adults with non-spousal dependent coverage. The non-targeted control group showed virtually no growth in non-spousal dependent coverage over this period. We also observe a significant but smaller decline (decrease of 2.4 percentage points) in the number of uninsured young adults in the ACA target group in 2010. This decline reverses the trend between 2008 and 2009, when the number of uninsured targeted young adults increased by a significant 3.0 percentage points. The share of the non-targeted comparison group that was uninsured also increased significantly between 2008 and 2009 but remained flat in 2010 . The percentage of individuals in both the targeted and comparison groups with private coverage in their own name or that of a spouse fell during the recession of 2008 to 2009. This rate also declined in 2010 for targeted young adults, although at a slower rate than in the prior year, while the corresponding rate for the comparison population remained fairly steady.

These simple tabulations do not adjust for possible shifts in the characteristics of the study population during the study period, the circumstances in which they live, or underlying economic forces. The Great Recession may have had differential impacts on the targeted young adults and the older comparison group. For example, according to the CPS, the share of targeted young adults living with their parents rose by $17.8 \%$ between 2005 and 2010 (from $37.1 \%$ to 43.7\%), while the share of our comparison group living at home was lower but grew more sharply, by nearly a third (from $13.3 \%$ to $17.2 \%$ ). Since the likelihood of being covered on a 
parent's plan is higher for those living with parents (data not shown), this shift underscores the importance of adjusting for underlying trends in analysis of ACA impact.

Table 3 compares characteristics of the ACA-eligible to the older comparison group. All of the differences in this table are statistically significant, although few are of substantial magnitude. Notably, but not surprisingly, comparison group members are more likely to be married, to have completed a bachelors or advanced degree, and to have higher income as a percentage of the federal poverty level. The young adults in the ACA target population, on the other hand, are more likely to live with a parent and to be eligible for dependent coverage under a state law than their older counterparts.

\section{Econometric Results}

Like the descriptive findings, our econometric models show a large and statistically significant impact of the ACA dependent coverage reform. Difference-in-differences estimates from the Models 1 and 2 are shown in Table 4 (detailed results available from the authors). Percentage point changes in the first column of results in the table (Model 1) represent the overall change in young adult coverage in 2010. While eligibility for state reforms are controlled for in Model 1, this model does not distinguish the effect of the ACA from possible contributions of prior state laws for young adults eligible for both. This model shows a statistically significant 5.3 percentage point increase in non-spousal dependent coverage accompanied by a significant 3.5 percentage point decline in the uninsured rate among young adults eligible for expanded dependent coverage under the ACA. In this specification, we also find a statistically significant decline of 2.1 percentage points in own-name or spousal coverage among targeted young adults. This decline may indicate that some individuals substituted dependent coverage for other forms 
of private insurance, although the decline in the share of the population uninsured indicates that many of those gaining dependent coverage did not switch from other sources. ${ }^{3}$

The second and third columns of results in Table 4 provide DD estimates from models with full sets of interactions between state and federal reforms allowing us to separate federal and state policy effects (Model 2). The DD estimators in the second column measure changes in coverage in the population of young adults targeted for dependent coverage under both the ACA and prior state reforms (i.e., the sum of coefficients described above), and estimates in the third column show the impact of the ACA on the population targeted by the federal expansion alone. The estimate of growth in non-spousal dependent coverage for the latter group (4.5 percentage points) is consistent with, but lower than, the estimate from the Model 1 that does not include state and federal policy interactions (5.3 percentage points). The estimates of impact on the uninsured rate in these two models differ little (declines of 3.8 and 3.5 percentage points, respectively), both showing that the policy is linked to a significant drop in uninsured young adults. The estimate of private coverage crowd out among those targeted for dependent coverage under the ACA but not state reforms shown in the third column (2.0 percentage points) is about the same as the estimate in Model 1 (2.1 percentage points), but does not reach statistical significance. Our estimate of private insurance crowd out in the population targeted by both expanded dependent coverage under the ACA and prior state reforms shown in the second column (1.2 percentage points) is also not statistically significant. None of the models find crowd out of public coverage.

The impact of the ACA on young adults who were also targeted under prior state reforms is shown in the second column of Table 4 ( 8.7 percentage points) appears to be about twice as great as the estimated impact in the population eligible under only the ACA in column three ( 4.5 
percentage points). While the magnitude of estimates of the incremental impact on dependent coverage and the likelihood of being uninsured for those targeted under both federal and state reforms is large, the difference between these estimates shown in the second and third columns under Model 2 does not reach conventional levels of statistical significance $(\mathrm{p}=0.068$ and $\mathrm{p}=0.173$, respectively).

\section{Sensitivity Analysis}

Results of sensitivity tests are presented in Table 5. The first set of results (Model 3) is limited to residents of states that did not enact dependent coverage expansions. The DD coefficients from these models, and their levels of statistical significance, are nearly identical to those estimated for the state-ineligible population in Model 2 shown in Table 4. This test confirms that the ACA increased dependent coverage and reduced the number of uninsured among targeted young adults apart from any potentially confounding state expansion effects.

To test whether our models are sensitive to inclusion of student variables, we examined an alternative specification of Model 1 that excluded these variables (Model 4) and another that included full-time students ages 19 to 23 in the target population (Model 5). In both cases, our findings of policy impact did not change (Table 5). We did find a somewhat smaller, but still statistically significant, increase in non-spousal dependent coverage in the model including fulltime students, although this was expected as this group is unaffected by the policy change. Finally, we also tested the robustness of our model by conducting a "placebo" regression without 2010 data and assuming that the ACA was implemented in 2009 (Model 6, Table 5). If our finding of policy impact was an artifact of our model specification, this model would likely show a false significant policy impact. It did not, reinforcing our confidence in the validity of our model specification. 


\section{$\underline{\text { Discussion }}$}

Our analysis shows that the ACA dependent coverage expansion led to a rapid and substantial increase in the share of young adults with dependent coverage and a reduction in their uninsured rate in the early months of implementation. Although the requirement to offer coverage to young adults was effective with the first plan renewal starting in late September 2010, favorable tax treatment of premiums was extended to young adults up to age 26 starting in March, encouraging early adoption. In fact, some employers and insurers were reported to have begun enrollment of dependents shortly after ACA enactment in March 2010 (USDOL, EBSA n.d.). In models controlling for prior state expansions, but without interactions between state and federal reforms (Model 1), we attribute to the ACA dependent coverage rules a more than 25\% rise in the share of targeted young adults with non-spousal dependent coverage (a 5.3 percentage point increase) and a nearly $10 \%$ drop in their uninsured rate (a 3.5 percentage point decline) between 2009 and 2010. This decline in the uninsured translates to about 716,000 young adults gaining coverage as a result of the ACA in 2010.

Our findings indicate that response to the ACA dependent coverage rule change was very rapid following its implementation date of September 23, 2010. Rapid enrollment may have been encouraged by high public awareness of the ACA dependent coverage rules. As early as April 2010, fully 70\% of the public reported knowing about these rules (KFF 2010). The weak economy may also have spurred dependent coverage take up by disproportionately limiting young adults' access to coverage through their own jobs.

In contrast to studies of earlier state young adult reforms (Monheit et al. 2011; Levine, McKnight, and Heep 2011), our results do not suggest that the increase in coverage of young 
adults as dependents occurred at the cost of a decline in other forms of private coverage. If prior state laws had effectively led to more young adults in dependent coverage, then we would have expected a more modest policy impact of the ACA on that group in 2010. To the contrary, findings from our models including interactions between federal and prior state reforms suggest (without achieving conventional levels of statistical significance) that take-up of dependent coverage in 2010 may have been greater among those who were targeted by a state expansion. It may be that the state reforms "primed the pump" for rapid take-up under the federal rules. We note that our measure of eligibility for state reforms does not account for parental coverage status and thus overstates actual young adult eligibility. Nevertheless, the state laws may have raised awareness of the possibility of dependent coverage even among young adults ineligible under restrictive state laws. This possibility is corroborated by reports of state regulators hearing frequently from frustrated consumers who were ineligible for state expansions due to employer self-insurance or other eligibility limitations prior to the ACA (Cantor et al. 2012). If the "priming" hypothesis is correct, take-up among ACA-targeted young adults who were not eligible under prior state laws will likely grow substantially over time.

Information available in the CPS places some limitations on our analysis. We were not able to directly observe the timing of insurance changes because the CPS employs an annual reference period for coverage questions. Moreover, CPS respondents are asked about coverage in March following each calendar year reference period, making its recall period as long as 15 months, raising the possibility of recall bias. Analysts have suggested that some respondents may report coverage status after the close of the reporting year (i.e., between January and March) (Pascale 2007). If this occurred, we may have overstated the impact of the dependent coverage 
reform in 2010 especially if the high salience of the new ACA rules led to reporting differences between eligible young adults and comparison group members.

The CPS also does not provide information about parents' insurance coverage or other characteristics except when young adults live with their parents, so we could not systematically adjust for the availability of parental coverage. We compensate for this gap by controlling at the state level for the rate of employer-sponsored coverage and employer self-insurance. Moreover, our models adjust for unmeasured differences among states and over time by including state and time fixed effects and controls for state-specific time trends.

\section{Conclusions}

We find that the ACA dependent coverage rules led to a rapid and large reduction in the number of uninsured young adults. Thus, coverage of young adults on parents' health plans is likely to be an important feature of the health insurance landscape well into the future. The benefits of this new reality to young adults and their families are clear, but this trend is not without costs. In particular, family premiums will increase as more young adults are enrolled. Further, in 2014 when the ACA individual coverage mandate takes effect and the limited anticrowd out provisions in the ACA will end, the availability of dependent coverage may attract comparatively healthy young adults, leaving non-group plans with higher average risk and premiums. Such a shift may also increase the cost of health insurance tax credits available through health benefit exchanges. In addition, businesses that employ primarily young adults may become less likely to offer coverage as fewer young workers seek their own health benefits. Still, the ACA young adult dependent coverage expansion represents a rare public policy success in the effort to cover the uninsured. 


\section{References}

Ai, C., and E. C. Norton. 2003. "Interaction Terms in Logit and Probit Models." Economics Letters 80 (1): 123-9.

Antwi, Y.A., A.S. Moriya, and K. Simon. "Effects of Federal Policy to Insure Young Adults:Evidence from the 2010 Affordable Care Act Dependent Coverage Mandate." Cambridge MA: National Bureau of Economic Research Working Paper \#18200.

Buchmueller, T., and J. DiNardo. 2002. "Did Community Rating Induce an Adverse Selection Death Spiral? Evidence from New York, Pennsylvania and Connecticut.” American Economic Review 92 (1): 280-94.

Bureau of Labor Statistics (BLS). n.d. "Local Area Unemployment Statistics: Tables and Maps Created by BLS" [accessed on February 8, 2012]. Available at http://www.bls.gov/lau/tables.htm

Callahan, S. T., and W. O. Cooper. 2005. "Uninsurance and Health Care Access among Young Adults in the United States." Pediatrics 116 (1): 88-95.

Cantor, J. C., D. Belloff, A. C. Monheit, D. DeLia, and M. Koller. 2012. “Expanding Dependent Coverage for Young Adults: Lessons from State Initiatives." Journal of Health Politics, Policy and Law 37 (1): 99-128.

Claxton, G., M. Rae, N. Panchal, J. Lundy, A. Damico, A. Osei-Anto, K. Kenward, H. Whitmore, and J. Pickreign. 2011. "Employer Health Benefits: 2011 Annual Survey" [accessed on February 8, 2012]. Available at http://ehbs.kff.org/pdf/2011/8225.pdf 
Davern, M., A. Jones Jr., J. Lepkowski, G. Davidson, and L. A. Blewett. 2007. "Estimating Regression Standard Errors with Data from the Current Population Survey's Public Use File." Inquiry 44 (2): 211-24.

DeNavas-Walt, C., B. D. Proctor, and J. C. Smith. 2011. "Income, Poverty, and Health Insurance Coverage in the United States: 2010" [accessed on February 8, 2012]. Available at http://www.census.gov/prod/2011pubs/p60-239.pdf

Fronstin, P. 2012. “The Impact of PPACA on Employment-Based Health Coverage of Adult Children to Age 26.” EBRI Notes 33 (1): 2-6.

Huber, P. J., 1967. "The behavior of maximum likelihood estimates under nonstandard conditions." In Vol. 1 of Proceedings of the Fifth Berkeley Symposium on Mathematical Statistics and Probability, 221-233. Berkeley: University of California Press.

Kaiser Family Foundation (KFF). 2010. "Kaiser Health Tracking Poll: April 2010-Findings" [accessed on June 7, 2012]. Available at http://www.kff.org/kaiserpolls/upload/8067F.pdf

Korn, E. L., and B. I. Graubard. 1990. "Simultaneous testing of regression coefficients with complex survey data: Use of Bonferroni t statistics.” American Statistician 44: 270-276.

Levine, P. B., R. McKnight, and S. Heep. 2011. "How Effective Are Public Policies to Increase Health Insurance Coverage among Young Adults?” American Economic Journal: Economic Policy 3 (1): 129-56.

Martinez, M. E., and R. A. Cohen. 2011. "Health Insurance Coverage: Early Release of Estimates from the National Health Interview Survey, January-June 2011" [accessed on 
March 20, 2012]. Available at

http://www.cdc.gov/nchs/data/nhis/earlyrelease/insur201112.pdf

Medical Expenditure Panel Survey-Insurance Component (MEPS). 2010a. "Table

I.B.2.b.(1)(2010) Percent of Private-Sector Enrollees That are Enrolled in Self-Insured Plans at Establishments That Offer Health Insurance by Firm Size and Selected Characteristics: United States, 2010" [accessed on April 9, 2012]. Available at http://meps.ahrq.gov/mepsweb/data_stats/summ_tables/insr/national/series_1/2010/tib2b 1.htm

Medical Expenditure Panel Survey-Insurance Component (MEPS). 2010b. “Table II.A.2(2010) Percent of Private-Sector Establishments That Offer Health Insurance by Firm Size and State: United States, 2010" [accessed on April 9, 2012]. Available at http://meps.ahrq.gov/mepsweb/data_stats/summ_tables/insr/state/series_2/2010/tiia2.htm

Mendes, E. 2011. "Fewer 18- to 26-Year-Olds in U.S. Uninsured in 2011" [accessed on February 8, 2012]. Available at http://www.gallup.com/poll/147422/Fewer-Year-Olds-Uninsured2011.aspx

Merluzzi, T. V., and R. C. Nairn. 1999. “Adulthood and Aging: Transitions in Health and Health Cognition." In LifeSpan Perspective on Health and Illness, edited by T. L. Whitman, T. V. Merluzzi, and R. D. White, pp. 189-206. Mahwah, NJ: Erlbaum.

Monheit, A. C., J. C. Cantor, D. DeLia, and D. Belloff. 2011. "How Have State Policies to Expand Dependent Coverage Affected the Health Insurance Status of Young Adults?" Health Services Research 46 (1 Pt 2): 251-67. 
Monheit, A. C., and B. Steinberg Schone. 2004. "How Has Small Group Market Reform Affected Employee Health Insurance Coverage?” Journal of Public Economics 88 (1-2): 237-54.

National Conference of State Legislatures (NCSL). 2010. “Covering Young Adults Through Their Parents' or Guardians' Health Policy" [accessed on April 5, 2012]. Available at http://www.ncsl.org/issues-research/health/dependent-health-coverage-stateimplementation.aspx

Nicholson, J. L., S. R. Collins, B. Mahato, E. Gould, C. Schoen, and S. D. Rustgi. 2009. "Rite of Passage? Why Young Adults Become Uninsured and How New Policies Can Help, 2009 Update" [accessed on April 5, 2012]. Available at http://www.commonwealthfund.org/ /media/Files/Publications/Issue\%20Brief/2009/Aug /1310_Nicholson_rite_of_passage_2009.pdf

Pascale, J. 2007. "Measuring Health Insurance in the U.S.” [accessed on April 5, 2012]. Available at http://www.census.gov/srd/papers/pdf/rsm2007-11.pdf

Pindyck, R. and D. Rubinfeld. 1998. Econometric Models and Economic Forecasts. Boston: McGraw Hill.

StataCorp. 2011. Stata (release 12) statistical software. College Station, TX: StataCorp LP. Sommers, B. D., and R. Kronick. 2012. "The Affordable Care Act and Insurance Coverage for Young Adults.” Journal of the American Medical Association 307 (9): 913-4. 
Sommers, B. D., and K. Schwartz. 2011. "2.5 Million Young Adults Gain Health Insurance Due to the Affordable Care Act" [accessed on February 8, 2012]. Available at http://aspe.hhs.gov/health/reports/2011/YoungAdultsACA/ib.shtml

U.S. Department of Labor (USDOL), Employee Benefits Security Administration (EBSA). n.d. "Fact Sheet: Young Adults and the Affordable Care Act: Protecting Young Adults and Eliminating Burdens on Families and Businesses" [accessed on April 5, 2012]. Available at http://www.dol.gov/ebsa/newsroom/fsdependentcoverage.html

White, H., 1980. "A heteroskedasticity-consistent covariance matrix estimator and a direct test for heteroskedasticity”. Econometrica 48: 817-838. 
Table 1: State Young Adult Dependent Coverage Expansion Laws, as of March 2011.

\begin{tabular}{|c|c|c|c|c|}
\hline State & $\begin{array}{c}\text { Expansion } \\
\text { Implementation } \\
\text { Date }\end{array}$ & $\begin{array}{c}\text { Upper Age } \\
\text { Limit } \\
\text { (Student/Non- } \\
\text { Student) }\end{array}$ & $\begin{array}{c}\text { Premium } \\
\text { Rules }\end{array}$ & Eligibility Criteria \\
\hline Colorado & $1 / 1 / 2006$ & $25 / 25$ & $\begin{array}{l}\text { Group - Small } \\
\text { group } \\
\text { Parent -Other } \\
\text { markets }\end{array}$ & Unmarried \\
\hline Connecticut & $1 / 1 / 2009$ & $26 / 26$ & Group & $\begin{array}{c}\text { Unmarried } \\
\text { All in state \& out-of-state full time } \\
\text { students }\end{array}$ \\
\hline Delaware & $6 / 1 / 2007$ & $24 / 24$ & Parent & $\begin{array}{l}\text { Unmarried and no dependents } \\
\text { In state \& out-of-state full time students }\end{array}$ \\
\hline Florida & $\begin{array}{l}7 / 1 / 2007 \\
10 / 1 / 2008\end{array}$ & $\begin{array}{l}25 / 25 \\
30 / 30\end{array}$ & Parent & $\begin{array}{l}\text { Unmarried and no dependents } \\
\text { Lives with parent or is a student (2007) } \\
\text { All in state \& out-of-state students (2008) }\end{array}$ \\
\hline Idaho & $7 / 1 / 2007$ & $25 / 21$ & Group & Unmarried \\
\hline Illinois & $6 / 1 / 2009$ & $26 / 26$ & Parent & Unmarried \\
\hline Indiana & $7 / 1 / 2007$ & $24 / 24$ & Group & None \\
\hline Iowa & $7 / 1 / 2008$ & No Limit / 25 & Either & $\begin{array}{c}\text { Unmarried } \\
\text { Lives in state \& out-of-state full time } \\
\text { students }\end{array}$ \\
\hline Kentucky & $7 / 15 / 2008$ & $26 / 26$ & Either & Unmarried \\
\hline Louisiana & $1 / 1 / 2009$ & $24 / 21$ & Group & Unmarried \\
\hline Maine & $9 / 20 / 2007$ & $25 / 25$ & Group & $\begin{array}{l}\text { Unmarried and no dependents } \\
\text { All in state \& out-of-state full time } \\
\text { students }\end{array}$ \\
\hline Maryland & $1 / 1 / 2008$ & $25 / 25$ & Group & Unmarried \\
\hline Massachusetts & $1 / 1 / 2007$ & $26 / 21$ & Group & $\begin{array}{l}\text { All in state \& out-of-state full time } \\
\text { students }\end{array}$ \\
\hline Minnesota & $1 / 1 / 2008$ & $25 / 25$ & Group & Unmarried \\
\hline
\end{tabular}

Continued next page 
Table 1 (Continued): State Young Adult Dependent Coverage Expansion Laws, as of March 2011.

\begin{tabular}{|c|c|c|c|c|}
\hline State & $\begin{array}{c}\text { Expansion } \\
\text { Implementation } \\
\text { Date }\end{array}$ & $\begin{array}{l}\text { Upper Age } \\
\text { Limit } \\
\text { (Student/Non- } \\
\text { Student) }\end{array}$ & $\begin{array}{c}\text { Premium } \\
\text { Rules }\end{array}$ & Eligibility Criteria \\
\hline Missouri & $1 / 1 / 2008$ & $25 / 25$ & Either & $\begin{array}{c}\text { Unmarried } \\
\text { Resides in state }\end{array}$ \\
\hline Montana & $1 / 1 / 2008$ & $25 / 25$ & Group & Unmarried \\
\hline $\begin{array}{l}\text { New } \\
\text { Hampshire }\end{array}$ & $9 / 15 / 2007$ & $26 / 26$ & Parent & $\begin{array}{c}\text { Unmarried } \\
\text { All in state \& out-of-state students }\end{array}$ \\
\hline New Jersey & $\begin{array}{l}1 / 1 / 2006 \\
1 / 1 / 2009\end{array}$ & $\begin{array}{l}30 / 30 \\
31 / 31\end{array}$ & Parent & $\begin{array}{l}\text { Unmarried and no dependents } \\
\text { All in state \& out-of-state full time students }\end{array}$ \\
\hline New Mexico & $7 / 1 / 2003$ & $25 / 25$ & Group & Unmarried \\
\hline New York & $9 / 1 / 2009$ & $30 / 30$ & Parent & $\begin{array}{c}\text { Unmarried } \\
\text { Must reside or work in state or in insurer } \\
\text { service area }\end{array}$ \\
\hline North Dakota & $7 / 1 / 1995$ & $26 / 22$ & Group & $\begin{array}{l}\text { Unmarried } \\
\text { Non-students must reside with parent }\end{array}$ \\
\hline Ohio & $7 / 1 / 2010$ & $28 / 28$ & Either & $\begin{array}{l}\text { Unmarried } \\
\text { All in state \& out-of-state full time students }\end{array}$ \\
\hline Pennsylvania & $9 / 1 / 2009$ & $30 / 30$ & Parent & $\begin{array}{l}\text { Unmarried } \\
\text { All in state \& out-of-state full time students }\end{array}$ \\
\hline Rhode Island & $1 / 1 / 2007$ & $25 / 19$ & Group & Unmarried \\
\hline South Dakota & $\begin{array}{c}2005 \\
7 / 1 / 2007\end{array}$ & $\begin{array}{l}24 / 19 \\
30 / 19\end{array}$ & Parent & Unmarried \\
\hline Texas & $1 / 1 / 2004$ & No Limit / 25 & Group & $\begin{array}{c}\text { Unmarried } \\
\text { All in state \& out-of-state full time students }\end{array}$ \\
\hline
\end{tabular}

Continued next page 
Table 1 (Continued): State Young Adult Dependent Coverage Expansion Laws, as of March 2011.

\begin{tabular}{|c|c|c|c|c|}
\hline State & $\begin{array}{c}\text { Expansion } \\
\text { Implementation } \\
\text { Date }\end{array}$ & $\begin{array}{l}\text { Upper Age } \\
\text { Limit } \\
\text { (Student/Non- } \\
\text { Student) }\end{array}$ & $\begin{array}{l}\text { Premium } \\
\text { Rules }\end{array}$ & Eligibility Criteria \\
\hline Utah & $1 / 1 / 1995$ & $26 / 26$ & Parent & $\begin{array}{c}\text { Unmarried } \\
\text { All in state \& out-of-state full time students }\end{array}$ \\
\hline Virginia & $7 / 1 / 2007$ & $25 / 25$ & Group & None \\
\hline Washington & $1 / 1 / 2009$ & $25 / 25$ & Either & Unmarried \\
\hline $\begin{array}{l}\text { West } \\
\text { Virginia }\end{array}$ & $7 / 1 / 2007$ & $25 / 25$ & Group & Unmarried \\
\hline Wisconsin & $1 / 2 / 2010$ & $27 / 27$ & Group & Unmarried \\
\hline
\end{tabular}

Source: Authors' review of state regulatory guidance and interviews with state officials.

Note: State expansions generally apply to all regulated insurance markets and the state's health benefit plan for public employees with two exceptions. Idaho expansion applies only to the individual and small group markets. Minnesota expansion excludes the state health benefit plan. 
Table 2. Health Insurance Status of Young Adults Targeted for Dependent Coverage under the Affordable Care Act and Older Comparison Group Members, Calendar Years 2004-2010

\begin{tabular}{|c|c|c|c|c|c|c|c|}
\hline \multirow{3}{*}{$\begin{array}{l}\text { Population and Source of } \\
\text { Coverage }\end{array}$} & \multicolumn{7}{|c|}{ Year } \\
\hline & & & & & & & \\
\hline & 2004 & 2005 & 2006 & 2007 & 2008 & 2009 & 2010 \\
\hline \multicolumn{8}{|l|}{ Targeted Young Adults $^{\mathrm{a}}$} \\
\hline Private, non-spouse dependent & 18.7 & 18.9 & 17.9 & 18.0 & 18.5 & 19.1 & $25.1^{\dagger}$ \\
\hline Private, self or spouse & 37.8 & 37.3 & 38.5 & 38.5 & 36.9 & $31.9^{\dagger}$ & $28.6^{\dagger}$ \\
\hline Public & 15.2 & 15.1 & 14.3 & 15.5 & 16.5 & 17.8 & 18.0 \\
\hline None & 34.6 & 35.2 & 35.4 & 34.3 & 34.3 & $37.3^{\dagger}$ & $34.9^{\dagger}$ \\
\hline \multicolumn{8}{|l|}{ Comparison Group $^{b}$} \\
\hline Private, non-spouse dependent & 4.1 & 4.2 & 4.1 & 4.0 & 4.3 & 4.4 & 4.8 \\
\hline Private, self or spouse & 63.9 & 62.8 & 61.6 & 62.6 & 60.7 & $56.6^{\dagger}$ & 55.5 \\
\hline Public & 11.6 & 12.4 & 11.6 & 11.2 & 12.6 & 13.7 & 14.2 \\
\hline None & 24.9 & 25.2 & 26.8 & 26.1 & 26.8 & $29.4^{\dagger}$ & 29.9 \\
\hline
\end{tabular}

Note: Percentages sum to more than $100 \%$ because some individuals may have more than one type of coverage.

${ }^{a}$ Ages 19-23 years (excluding full-time students) and those ages 24 or 25 regardless of student status

${ }^{\mathrm{b}}$ Ages 27 to 30

${ }^{\dagger}$ Significantly different than prior year estimate at $\mathrm{p}<0.01$ level 
Table 3: Population Characteristics of Young Adults Targeted for Dependent Coverage under the Affordable Care Act and Older Comparison Group Members, 2004-2010

\begin{tabular}{|c|c|c|}
\hline \multirow[b]{2}{*}{ Characteristics* } & \multicolumn{2}{|c|}{$\begin{array}{l}\text { Percentage (except where noted) } \\
\text { (Standard Errors Shown in Parentheses) }\end{array}$} \\
\hline & $\begin{array}{l}\text { ACA Targeted } \\
\text { Young Adults } \\
\end{array}$ & Comparison Group ${ }^{\ddagger}$ \\
\hline Age (mean) & $\begin{array}{c}22.6 \\
(0.008)\end{array}$ & $\begin{array}{c}28.5 \\
(0.005)\end{array}$ \\
\hline Female & $\begin{array}{l}48.0 \\
(0.19)\end{array}$ & $\begin{array}{l}50.0 \\
(0.20)\end{array}$ \\
\hline \multicolumn{3}{|l|}{ Race/Ethnicity } \\
\hline White non-Hispanic & $\begin{array}{c}58.7 \\
(0.23)\end{array}$ & $\begin{array}{c}59.7 \\
(0.24)\end{array}$ \\
\hline Hispanic & $\begin{array}{l}21.1 \\
(0.18)\end{array}$ & $\begin{array}{c}20.3 \\
(0.19)\end{array}$ \\
\hline Black non-Hispanic & $\begin{array}{l}14.7 \\
(0.17)\end{array}$ & $\begin{array}{c}13.1 \\
(0.17)\end{array}$ \\
\hline Other non-Hispanic & $\begin{array}{c}5.5 \\
(0.10)\end{array}$ & $\begin{array}{c}7.0 \\
(0.12)\end{array}$ \\
\hline \multicolumn{3}{|l|}{ Marital Status } \\
\hline Married & $\begin{array}{c}20.5 \\
(0.19)\end{array}$ & $\begin{array}{c}48.0 \\
(0.25)\end{array}$ \\
\hline Widowed & $\begin{array}{c}0.1 \\
(0.02)\end{array}$ & $\begin{array}{c}0.3 \\
(0.02)\end{array}$ \\
\hline Divorced & $\begin{array}{c}1.6 \\
(0.05)\end{array}$ & $\begin{array}{c}5.0 \\
(0.10)\end{array}$ \\
\hline Separated & $\begin{array}{c}1.6 \\
(0.05)\end{array}$ & $\begin{array}{c}2.6 \\
(0.07)\end{array}$ \\
\hline Never married & $\begin{array}{c}76.1 \\
(0.20)\end{array}$ & $\begin{array}{c}44.1 \\
(0.25)\end{array}$ \\
\hline \multicolumn{3}{|l|}{ Education } \\
\hline Less than high school & $\begin{array}{c}15.9 \\
(0.16)\end{array}$ & $\begin{array}{c}12.3 \\
(0.16)\end{array}$ \\
\hline High school or equivalent & $\begin{array}{c}37.7 \\
(0.21)\end{array}$ & $\begin{array}{c}28.5 \\
(0.21)\end{array}$ \\
\hline Some college & $\begin{array}{c}30.4 \\
(0.20)\end{array}$ & $\begin{array}{c}27.9 \\
(0.21)\end{array}$ \\
\hline Bachelors degree & $\begin{array}{c}14.5 \\
(0.17)\end{array}$ & $\begin{array}{c}22.9 \\
(0.20)\end{array}$ \\
\hline Advanced degree & $\begin{array}{c}1.5 \\
(0.05)\end{array}$ & $\begin{array}{c}8.4 \\
(0.14)\end{array}$ \\
\hline
\end{tabular}

Continued next page 
Table 3: Population Characteristics of Young Adults Targeted for Dependent Coverage under the Affordable Care Act and Older Comparison Group Members, 2004-2010 (CONTINUED)

\begin{tabular}{|c|c|c|}
\hline \multirow[b]{2}{*}{ Characteristics* } & \multicolumn{2}{|c|}{$\begin{array}{c}\text { Percentage (except where noted) } \\
\text { (Standard Errors Shown in Parentheses) }\end{array}$} \\
\hline & $\begin{array}{l}\text { ACA Targeted } \\
\text { Young Adults }\end{array}$ & Comparison Group ${ }^{\ddagger}$ \\
\hline \multicolumn{3}{|c|}{ Income as a percentage of the federal poverty level } \\
\hline$<100 \% \mathrm{FPL}$ & $\begin{array}{c}20.4 \\
(0.19)\end{array}$ & $\begin{array}{c}14.1 \\
(0.16)\end{array}$ \\
\hline $100-199 \%$ FPL & $\begin{array}{c}22.2 \\
(0.19)\end{array}$ & $\begin{array}{l}18.8 \\
(0.19)\end{array}$ \\
\hline $200-349 \% \mathrm{FPL}$ & $\begin{array}{c}26.3 \\
(0.20)\end{array}$ & $\begin{array}{c}26.2 \\
(0.21)\end{array}$ \\
\hline$\geq 350 \%$ FPL & $\begin{array}{c}31.1 \\
(0.22)\end{array}$ & $\begin{array}{l}40.9 \\
(0.25)\end{array}$ \\
\hline \multicolumn{3}{|l|}{ Student Status } \\
\hline Not a student & $\begin{array}{c}69.6 \\
(0.20)\end{array}$ & -- \\
\hline Part-time student & $\begin{array}{c}3.1 \\
(0.07)\end{array}$ & -- \\
\hline Full-time student & $\begin{array}{c}6.9 \\
(0.11)\end{array}$ & -- \\
\hline Unknown $^{\S}$ & $\begin{array}{l}20.5 \\
(0.17)\end{array}$ & $\begin{array}{c}100 \\
(0.00)\end{array}$ \\
\hline \multicolumn{3}{|l|}{ Living situation } \\
\hline Not living with a parent & $\begin{array}{c}60.1 \\
(0.23)\end{array}$ & $\begin{array}{c}84.4 \\
(0.18)\end{array}$ \\
\hline Living with a parent & $\begin{array}{c}39.9 \\
(0.23)\end{array}$ & $\begin{array}{c}15.6 \\
(0.18)\end{array}$ \\
\hline \multicolumn{3}{|l|}{ Health status } \\
\hline Excellent & $\begin{array}{c}38.2 \\
(0.23)\end{array}$ & $\begin{array}{c}36.4 \\
(0.24)\end{array}$ \\
\hline Very good & $\begin{array}{c}34.0 \\
(0.22)\end{array}$ & $\begin{array}{c}35.2 \\
(0.23)\end{array}$ \\
\hline Good & $\begin{array}{l}22.7 \\
(0.19)\end{array}$ & $\begin{array}{l}22.5 \\
(0.20)\end{array}$ \\
\hline Fair or poor & $\begin{array}{c}5.1 \\
(0.10)\end{array}$ & $\begin{array}{c}5.9 \\
(0.11)\end{array}$ \\
\hline
\end{tabular}

Continued next page 
Table 3: Population Characteristics of Young Adults Targeted for Dependent Coverage under the Affordable Care Act and Older Comparison Group Members, 2004-2010 (CONTINUED)

Percentage (except where noted)

(Standard Errors Shown in Parentheses)

\begin{tabular}{lcc} 
& $\begin{array}{c}\text { ACA Targeted } \\
\text { Characteristics }^{*}\end{array}$ & \\
\hline Young Adults & \\
Eligibility under state dependent coverage reform law & Comparison Group $^{\ddagger}$ \\
Eligible & 19.5 & 3.2 \\
& $(0.18)$ & $(0.10)$ \\
\hline
\end{tabular}

ACA, 2010 Patient Protection and Affordable Care Act; FPL, federal poverty level, DD difference-in-differences

*All differences significant at $\mathrm{p}<0.0001$ two-tailed t-test or Chi-square test (except student status)

$\uparrow$ Persons age 19-23 years old and not full-time students and persons 24 or 25 regardless of student status

*Persons age 27 to 30

${ }^{\S} \mathrm{CPS}$ only collects information on student status for persons ages 16 through 24 .

"Based on young adult qualifying characteristics and year of state law implementation. 
Table 4: Multivariate Regression Difference-in-Differences Estimates of the Impact of the Affordable Care Act (ACA) Dependent Coverage Eligibility Expansion

\section{Percentage Point Change in Source of Insurance Status}

(Standard Error in Parentheses)

\begin{tabular}{|c|c|c|c|}
\hline \multirow[b]{3}{*}{ Source of Coverage } & \multicolumn{3}{|c|}{ (Standard Error in Parentheses) } \\
\hline & \multirow{2}{*}{$\begin{array}{c}\text { Model } 1 \\
\begin{array}{c}\text { Full ACA Target } \\
\text { Population* }\end{array}\end{array}$} & \multicolumn{2}{|c|}{ Model 2} \\
\hline & & $\begin{array}{c}\text { Targeted under ACA } \\
\text { and Prior State } \\
\text { Reforms }^{\wedge}\end{array}$ & $\begin{array}{c}\text { Targeted under the } \\
\text { ACA but not State } \\
\text { Reforms }\end{array}$ \\
\hline $\begin{array}{l}\text { Private-non-spouse } \\
\text { dependent }{ }^{\dagger}\end{array}$ & $\begin{array}{c}5.3^{\ddagger} \\
(0.6)\end{array}$ & $\begin{array}{l}8.7^{\ddagger} \\
(2.5)\end{array}$ & $\begin{array}{l}4.5^{*} \\
(0.9)\end{array}$ \\
\hline Private-Self or Spouse & $\begin{array}{l}-2.1^{\S} \\
(0.7)\end{array}$ & $\begin{array}{c}1.2 \\
(3.3)\end{array}$ & $\begin{array}{l}-2.0 \\
(1.1)\end{array}$ \\
\hline Public & $\begin{array}{c}0.6 \\
(0.6)\end{array}$ & $\begin{array}{l}-0.6 \\
(2.6)\end{array}$ & $\begin{array}{c}0.5 \\
(1.0)\end{array}$ \\
\hline None & $\begin{array}{l}-3.5^{+} \\
(0.8)\end{array}$ & $\begin{array}{l}-8.3^{\S} \\
(3.6)\end{array}$ & $\begin{array}{l}-3.8^{\S} \\
(1.2)\end{array}$ \\
\hline
\end{tabular}

* Models control for eligibility for prior state reforms but do not include interactions of state and federal policy effects.

$\dagger$ Other than on the plan of a spouse

${ }^{\wedge}$ See Methods section for calculation of standard errors.

$\S p<0.05, \$ p<0.001$ for two-tailed test. 
Table 5: Multivariate Regression Difference-in-Differences Estimates for Sensitivity Analyses of the Impact of the Affordable Care Act (ACA) Dependent Coverage Eligibility Expansion

\begin{tabular}{|c|c|c|c|c|}
\hline \multirow[b]{3}{*}{ Source of Coverage } & \multicolumn{4}{|c|}{$\begin{array}{c}\text { Percentage Point Change in Source of Insurance Status } \\
\text { (Standard Error in Parentheses) }\end{array}$} \\
\hline & Model 3 & Model 4 & Model 5 & Model 6 \\
\hline & $\begin{array}{l}\text { Non-Reform } \\
\text { States Only }\end{array}$ & $\begin{array}{c}\text { No Controls } \\
\text { for Student } \\
\text { Status }\end{array}$ & $\begin{array}{c}\text { No Controls for } \\
\text { Student Status \& } \\
\text { Sample Includes } \\
\text { Full-Time } \\
\text { Students Ages } \\
\text { 19-23 }\end{array}$ & $\begin{array}{l}\text { Placebo } \\
\text { Model }^{*}\end{array}$ \\
\hline $\begin{array}{c}\text { Private-non-spouse } \\
\text { dependent } \dagger\end{array}$ & $\begin{array}{l}4.3^{\ddagger} \\
(0.9)\end{array}$ & $\begin{array}{l}5.4^{\sharp} \\
(0.6)\end{array}$ & $\begin{array}{l}3.9^{\ddagger} \\
(0.6)\end{array}$ & $\begin{array}{c}0.3 \\
(0.5)\end{array}$ \\
\hline Private-self or spouse & $\begin{array}{l}-1.9 \\
(1.2)\end{array}$ & $\begin{array}{l}-2.2^{\S} \\
(0.7)\end{array}$ & $\begin{array}{l}-0.3 \\
(0.7)\end{array}$ & $\begin{array}{c}0.1 \\
(0.8)\end{array}$ \\
\hline Public & $\begin{array}{c}0.7 \\
(1.1)\end{array}$ & $\begin{array}{l}0.6 \\
(0.6)\end{array}$ & $\begin{array}{c}0.5 \\
(0.6)\end{array}$ & $\begin{array}{l}0.7 \\
(0.6)\end{array}$ \\
\hline None & $\begin{array}{l}-3.6^{\S} \\
(1.3)\end{array}$ & $\begin{array}{l}-3.5^{+} \\
(0.8)\end{array}$ & $\begin{array}{l}-3.5^{\ddagger} \\
(0.7)\end{array}$ & $\begin{array}{l}-0.9 \\
(0.8) \\
\end{array}$ \\
\hline
\end{tabular}

$\dagger$ Other than on the plan of a spouse

*Excludes 2011 CPS (reflecting coverage status in 2010) and falsely assumes that ACA young adult dependent coverage was implemented in 2009.

$\S \mathrm{p}<0.05, \$ \mathrm{p}<0.001$ for two-tailed test. 


\section{ENDNOTES}

${ }^{1}$ We treat 30 states as having implemented reforms for the purpose of this analysis. We exclude several states listed by the National Conference of State Legislatures (NCSL 2010) as having dependent coverage legislation (Georgia, Nevada, Oregon, Tennessee, and Wyoming) because these reforms either established dependent age thresholds at conventional levels (e.g., age 23 for full-time students) or are limited to dependents with work-related disabilities. We also exclude Nebraska because its 2010 expansion was limited to children "aging out" of standard dependent coverage, thus few would be eligible during our study period and we could not precisely determine their eligibility.

${ }^{2}$ Specifically, the term ST_TARGET ${ }_{\text {is }}^{*} \mathrm{FED}_{-} \mathrm{TARGET}_{\mathrm{i}}{ }^{*} \mathrm{YEAR}_{2010}$ is not included in Model 2 because it is perfectly co-linear with $\mathrm{ST}_{-} \mathrm{TARGET}_{\mathrm{is}}{ }^{*} \mathrm{ST} \mathrm{POLICY}_{\mathrm{st}}{ }^{*} \mathrm{FED}_{-} \mathrm{TARGET}_{\mathrm{i}}{ }^{*} \mathrm{YEAR}_{2010}$, and the term ST_TARGET ${ }_{\text {is }} * \mathrm{YEAR}_{2010}$ is not included because it is perfectly co-linear with $\mathrm{ST}_{-} \mathrm{TARGET}$ is $* \mathrm{ST}_{-} \mathrm{POLICY} \mathrm{st}_{\mathrm{s}} \mathrm{YEAR}_{2010}$.

${ }^{3}$ The CPS asks about coverage for the entire prior calendar year, thus, if properly answered, the negative coefficient on own-name and spousal coverage following ACA implementation should not be interpreted as indicating substitution of dependent for other sources of coverage.

However, as discussed below, many analysts believe that respondents may not accurately recall coverage over the course of the full year. If this is the case, the negative coefficient on nondependent private coverage may indicate partial substitution. 